\title{
Factors associated with the occurence of hyperbilirubinemia in infants
}

\author{
Yuni Arisandi ${ }^{1}$, Sodikin ${ }^{2}$ \\ 1,2Program Studi Ilmu Keperawatan, Fakultas Ilmu Kesehatan,Universitas Muhammadiyah Purwokerto
}

\begin{tabular}{l}
\hline ARTICLE INFO \\
\hline Article history: \\
Received: August 9, 2020 \\
Revised: August 20, 2020 \\
Accepted: August 30, 2020 \\
\hline
\end{tabular}

Keywords:

Hyperbilirubinemia, Type of Labor, Birth Weight, Age of Pregnancy, Gender, Asphyxia

\begin{abstract}
Hyperbilirubinemia is a problem that often occurs in newborns characterized by icterus, yellowish pigmentation of the skin, sclera, and nails. Many factors cause hyperbilirubinemia in infants such as the type of labor, birth weight, gestational age, gender, and asphyxia.This research aimed to discover the factors associated with the occurrence of hyperbilirubinemia in infants.This was a quantitative research with a retrospective cohort design. There were 83 respondents as the research sample taken using a random sampling technique. The research data were analyzed using the chi-square test and multivariate logistic regression. The majority of respondents underwent labor with actions (59 respondents $/ 71.1 \%$ ), delivered male babies (51 respondents / 61.4\%), delivered babies with normal birth weight (56 respondents / $67.5 \%$ ), had a full-term pregnancy (54 respondents / 65.1\%), and did not experience asphyxia (65 respondents / 78.3\%). In addition, most respondents gave birth to babies with hyperbilirubinemia (43 respondents / 51.8\%). Chisquare test results indicated a correlation between the type of labor $(\mathrm{p}=$ $0.008)$, birth weight $(\mathrm{p}=0.019)$, gestational age $(\mathrm{p}=0.000)$, and asphyxia ( $\mathrm{p}$ $=0.013$ ) with the incidence of hyperbilirubinemia. While the variable of gender $(p=0.106)$ had no correlation. The most influential factor was gestational age $(p=0.027)$ with an odds ratio of 4.011. In conclusion: The types of labor, birth weight, gestational age, and asphyxia have a correlation with the occurrence of hyperbilirubinemia.
\end{abstract}

This work is licensed under a Creative Commons Attribution 4.0 International License.

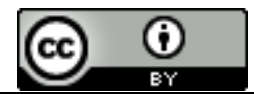

Corresponding Author:

Yuni Arisandi,

Faculty of Health Science,

Universitas Muhammadiyah Purwokerto

\section{INTRODUCTION}

The incidence of hyper-bilirubin in Nepal based on birth weight less than 2000 grams was 33 babies from 963 babies. It was found among the babies weighing 2000-2499 grams in 121 babies from the total 4629, those with 2500-2999 grams in 230 babies from the total 8290, and among the babies with more than 3000 grams in 169 babies from 4523 [1]. Widiawati's research [2] shows that the incidence of neonatal jaundice every year has always increased, such as in the Randen Mattaher Jambi Hospital. In 2014, there were 89 babies and in 2015 it was found in 102 babies. Based on a preliminary study in the Perinatology Room of the Banyumas Hospital, the incidence of hyperbilirubin in 2018 was $12.8 \%$ (486 cases out of 3790 births). This figure is much higher than in 2016 and 2017 which was only $7.02 \%$ (222 cases out of 3161 births), and $7.82 \%$ ( 273 cases out of 3488 births) respectively. There is an increase of the incidence from 2016-2018.

The incidence of neonatal jaundice in low birth weight (LBW) babies on average has caused a fatality [3].Another finding proved that several cases of complications of hyperbilirubinemia have caused kernal jaundice and bilirubin encephalopathy [4]. A prevention can be done if the causative factors have been identified in advance. An increase in bilirubin levels is due to several factors such as gestational age, birth weight, type of delivery and blood type [5]. Another study only mentioned two factors, type of delivery and the sex of the baby [6]. Based on the description of the problem, it is necessary to conduct research to determine 
the factors associated with the incidence of hyperbilirubin. It was conducted in the Perinatology Room of Banyumas Hospital.

\section{RESEARCH METHOD}

This is a quantitative study using a design of retrospective cohort study. The population in this study was all babies with hyperbilirubin in the Perinatology Room at Banyumas Hospital in January-December 2018. There were 486 babies. The method of data collection was by observing the patient's medical records. To determine the sample it was used a simple random sampling technique, it gave 83 respondents. The independent variable is the type of delivery, birth weight, gestational age, sex and asphyxia, and the dependent is the occurrence of hyperbilirubin. The instrument used in this study was the observation sheet. The data analysis employed chi square test and multiple logistic regression.

\section{RESULTS AND DISCUSSIONS}

\subsection{Bivariate analysis}

Table 1. The relationship between type of delivery, birth weight, gestational age, sex and asphyxia with the incidence of hyperbilirubin

\begin{tabular}{|c|c|c|c|c|c|c|c|}
\hline \multirow{3}{*}{ Variable } & \multicolumn{4}{|c|}{ Hyperbilirubin incidence } & \multirow{2}{*}{\multicolumn{2}{|c|}{ Total }} & \multirow{3}{*}{ p-value } \\
\hline & \multicolumn{2}{|c|}{ Hyperbilirubin } & \multicolumn{2}{|c|}{$\begin{array}{c}\text { Non- } \\
\text { hyperbilirubin }\end{array}$} & & & \\
\hline & f & $\%$ & f & $\%$ & $\mathbf{n}$ & $\%$ & \\
\hline \multicolumn{8}{|l|}{ Type of delivery } \\
\hline Labor with treatment & 36 & 83.7 & 23 & 57.5 & 59 & 77.1 & \multirow{2}{*}{0,008} \\
\hline Normal labor & 7 & 16.3 & 17 & 42.5 & 24 & 28.9 & \\
\hline \multicolumn{8}{|l|}{ Birth weight } \\
\hline Low birth weight & 19 & 44.2 & 8 & 20.0 & 27 & 32.5 & \multirow{2}{*}{0,019} \\
\hline Normal Birth weight & 24 & 55.8 & 32 & 80.0 & 56 & 67.5 & \\
\hline \multicolumn{8}{|l|}{ Gestational age } \\
\hline Preterm & 23 & 53.5 & 6 & 15.0 & 29 & 34.9 & \multirow[t]{2}{*}{0,000} \\
\hline Aterm & 20 & 46.5 & 34 & 85.0 & 54 & 65.1 & \\
\hline \multicolumn{8}{|l|}{ Sex } \\
\hline Male & 30 & 69.8 & 21 & 52.5 & 51 & 61.4 & \multirow[t]{2}{*}{0,106} \\
\hline Female & 13 & 30.2 & 19 & 47.5 & 32 & 38.6 & \\
\hline \multicolumn{8}{|l|}{ Asphyxia } \\
\hline Asphyxia & 14 & 32.6 & 4 & 10.0 & 18 & 21.7 & \multirow{3}{*}{0,013} \\
\hline Non asphyxia & 29 & 67.4 & 36 & 90.0 & 65 & 78.3 & \\
\hline Total & 43 & 100 & 40 & 100 & 83 & 100 & \\
\hline
\end{tabular}

The results show that of the 59 respondents of delivery with treatment, most of them (36) had babies with hyperbilirubin, while of the 24 respondents with normal labor, mostly (17) had non-hyperbilirubin babies. This partly corresponds with another study which indicates that the chance that a baby will experience hyperbilirubinemia if the mother experiences a non-spontaneous type of labor and the baby is born prematurely is $99 \%$. It means the delivery with treatment partly contribute for the case of hyperbilirubin [7]. Based on the statistics test, it obtained a p-value of $0.008(<0.05)$, indicating there is a relationship between the type of labor and the incidence of hyperbilirubin in infants. This factor is also mentioned in another study (Novie and Ade, 2010); another factor indicated to be associated with the case is gestational age. It is exlained further that babies born with treatment may not immediately cry at birth. The delay in crying results in in hemodynamic abnormalities so that respiratory depression can cause hypoxia throughout the body resulting in respiratory/metabolic acidosis which then can interfere with billirubin metabolism [8].

The data show that of the 27 respondents with low birth weight, 19 respondents had a case of hyperbilirubin, while among 56 respondents with normal birth weight, most (32 respondents) of them did not go with the case. A similar result is seen in another study [9], showing that out of 20 respondents with LBW, a small proportion of respondents, only $1(5.0 \%)$ experienced physiological jaundice and 19 ohers $(95.0 \%)$ underwent a pathological jaundice. LBW conditions cause the imperfect liver maturation (liver immaturity). Thus, the conjugation of indirect bilirubin to direct bilirubin in the liver is imperfect. The chi square test gave a p-value $0.019(<0.05)$, meaning that there is a relationship between birth weight and the incidence of hyperbilirubin in infants. This finding is in line with the results of research, proving a relationship between infant birth weight $(P=0.0001)$ and hyperbilirubinemia. [10] This also supported another study [5] that babies with low birth weight are due to immature hepatic function or liver function disorders such as hypoxia, hypoglycemia, acidosis, etc., resulting in increased bilirubin levels. 
The data show that of the 29 respondents with preterm gestational age, 23 of them had the hyperbilirubin case. Meanwhile, among 54 respondents who were at term, the majority (34 respondents) did not get the case. This is in line with another study showing that babies with preterm gestation ( $<37$ weeks), more then a half $(52.3 \%)$ experienced hyperbillirubin, while most babies with at term gestation (37-42 weeks), $71.5 \%$ ), do not have hyprebillirubin. [11] The chi square test obtained a p-value of $0.000(<0.05)$. It indicates a relationship between gestational age and the incidence of hyperbilirubin. The result is in line, that there is a relationship between gestational age and the incidence of neonatal jaundice [12]. This supports another research emphasizing that the incidence of neonatal jaundice in term infants (term) reaches $50 \%$ and in preterm (preterm infants), it is $58 \%$. [3]

It shows that of the 51 respondents with male babies, most of them (30 respondents) were with hyperbilirubin. Among 32 respondents with female babies, 19 babies did not have hyperbilirubin. This supports another study reporting that $68 \%$ of hyperbilirubinemia cases occurred in male infants [13]. The chi square test obtained p-value 0.106 ( $>0.05$ ), saying that no certain sex does asscoiate with the incidence of hyperbilirubin. It can happen equally in male and female babies. The result accords to another study emphazising no association of the sex of the baby and the incidence of neonatal jaundice [14].

The result of the research shows that of the 18 respondents with asphyxia, most of the babies (14 respondents) were with hyperbilirubin. Meanwhile from the 65 respondents with no asphyxia, most of their babies did not have any hyperbilirubin case. Neonatal risk factors that influence the incidence of neonatal jaundice are babies born with a history of asphyxia. This condition is caused by a lack of oxygen intake in the organs of the neonate, so that the function of the organs is not optimal. Asphyxia can also result in changes of liver function. This will lead to a lack of oxygen in the liver which can cause a jaundice in the long term and even a death in the short term [15]. Based on the results of the analysis, it shows a p-value $0.013(<0.05)$, saying that there is a relationship between asphyxia and the incidence of hyperbilirubin. This is in line with another study proving that statistically there is a significant relationship between the incidence of asphyxia and neonatal jaundice [16].

\subsection{Multivariate analysis}

Table 2 The factor mostly-associated with the incidence of hyperbilirubin

\begin{tabular}{lcccccc}
\hline Variable & B & S.E. & P value & \multicolumn{2}{c}{$\begin{array}{c}\text { Odds } \\
\text { ratio }\end{array}$} & \multicolumn{2}{c}{ 95\% C.I.for EXP(B) } \\
\hline Asphyixia & & & & Lower & Upper \\
Gestation age & 1.120 & .679 & 0.099 & 3.065 & .810 & 11.593 \\
Birth weight & 1.389 & .629 & 0.027 & 4.011 & 1.169 & 13.767 \\
Type of delivery & .437 & .640 & 0.495 & 1.548 & .442 & 5.423 \\
Constant & 1.029 & .571 & 0.072 & 2.798 & .914 & 8.568 \\
\hline
\end{tabular}

The factors mostly related to the incidence of hyperbilirubin Based on the results, it shows that the factor that mostly influences the incidence of hyperbilirubin is gestational age with a p-value of at least 0.027 and the greatest odds ratio of 4.011. The odds ratio indicates that gestational age has a greater chance than other variables by 4.011 times to cause hyperbilirubin. This finding supports another study, which proved that the risk factor that affects the occurrence of hyperbilirubinemia is gestational age. It also shows that gestational age has a 4 times chance of causing hyperbilirubin. This explains that the less gestational age, the greater the risk of causing hyperbilirubin [17]. Postterm gestational age has a higher risk of causing complications than at term gestation. [18] Explains that premature babies have a 6.319 times greater chance of experiencing neonatal jaundice than at term babies. In premature babies there is immaturity of the liver which causes conjugation and impaired excretion of bilirubin, causing jaundice. Lack of the enzyme glucorinyl transfer causes the conjugation of indirect bilirubin to direct bilirubin is not yet complete and the level of blood albumin which plays a role in the transport of bilirubin from the tissue to the liver are low.

\section{CONCLUSION}

Based on the analysis, it can be concluded that the factors causing hyeperbilurbin in babies are type of delivery, birth weight, gestational age, and asphyxia. It is also proved that the sex of the baby has no association with the incidence of hyperbilirubin. Among the factors the gestational age the most important contributor for the case by 4 times compared to other variables under this inquiry.

\section{REFERENCES}

[1] Tielsch, M. Steinhoff, J. Katz, J. Englund e Kuype, "Designs of two randomized, community-based trials to assess the impact of influenza immunization during pregnancy on respiratory illness among 
pregnant woman and their infants and reproductive outcomes in rural Nepal," BMC Pregnancy and Childbirth, vol. 15, n 40, 2016.

[2] Widiawati, "Hubungan sepsis neonatorum, BBLR dan asfiksia dengan kejadian ikterus pada bayi baru lahir," Riset Informasi Kesehatan, vol. 6, n 1, 2017.

[3] Puspita, "Pengaruh Berat Badan Lahir Rendah Terhadap Kejadian Ikterus Neonatorum Di Sidoarjo," Jurnal Berkala Epidemiologi, vol. 6, n 2, 2018.

[4] Maryunani e Sari , Asuhan Kegawatdaruratan Maternal dan Neonatal, Jakarta: Trans Info Medika, 2013.

[5] Hidayati e Rahmaswari, "Hubungan Faktor Ibu dan Faktor Bayi Dengan Kejadian Hiperbilirubinemia Pada Bayi Baru Lahir di RSUD Koja Tahun 2015," em Rakernas AIPKEMA, Jakarta Utara, 2016.

[6] Ranjkesh, "The Relationship between Neonatal Jaundice and Maternal and Neonatal Factors," Iranian Journal of Neonatology, vol. 7, $\mathrm{n}^{\circ}$ 1, 2015.

[7] Roselina, "Hubungan Jenis Persalinan dan Prematuritas dengan Hiperbilirubinemia di RS Persahabatan," Jurnal Vokasi Indonesia, vol. 1, n 1, 2013.

[8] Novie e Ade, "Faktor-Faktor Pada Ibu Bersalin Yang Berhubungan Dengan Kejadian Hiperbillirubin Pada Bayi Baru Lahir Di Rumah Sakit Dustira Cimahi Tahun 2009,” Jurnal Kesehatan Kartika, 2010.

[9] Yuliawati e Astutik, "Hubungan Faktor Perinatal Dan Neonatal Terhadap Kejadian Ikterus Neonatorum," Jurnal Ners dan Kebidanan, vol. 5, nº 2, 2018.

[10] Cholifah, "Faktor- Faktor Yang Berpengaruh Terhadap Hiperbilirubinemia Di RS Muhammadiyah Gersik," Universitas Muhammadiyah Sidoarjo, Sidoarjo, 2014.

[11] Faiqoh, "Hubungan Usia Gestasi Dan Jenis Persalinan Dengan Kadar Bilirubinemia Pada Bayi Ikterus Di RSUP NTB," Jurnal Kesehatan Prima, vol. 8, nº 2, 2014.

[12] Lestari, "Hubungan Berat Badan Lahir Bayi Dan Usia Kehamilan Dengan Kejadian Ikterus Neonatorum Di RSUD Sleman Tahun 2017.," Politeknik Kesehatan Kementerian Kesehatan Yogyakarta, Yogyakarta, 2017.

[13] R. Tazami , Mustarim e S. Syah, "Gambaran Faktor Risiko Ikterus Neonatorum pada Neonatus di Ruang Perinatologi RSUD Raden Mattaher Jambi,” Jurnal Jambi Medical, 2013.

[14] Yuliawati e Astutik, "Hubungan Faktor Perinatal Dan Neonatal Terhadap Kejadian Ikterus Neonatorum," Jurnal Ners dan Kebidanan, vol. 5, nº 2, 2018.

[15] Latama, "Hubungan Antara Apgar Score Dengan Ikterus Neonatorum Di RSUD Al-Ihsan Kabupaten Bandung," Bandung, 2014.

[16] Putri e Rositawati, "Hubungan BBLR Dan Asfiksia Dengan Kejadian Ikterus Neonatorum," Jurnal Obstretika Scientia, vol. 4, n $2,2016$.

[17] Wijaya, "Faktor risiko kejadian hiperbilirubinemia pada neonatus di ruang perinatologi RSUD Wangaya Kota Denpasar," Medicina, vol. 50, n² 2019.

[18] Darma, Kehamilan, Persalinan, Bayi Preterm \&Postterm Disertai Evidence Based, Jakarta: Noefikri, 2017. 